\title{
Распределенный брегговский отражатель с улучшенной угловой зависимостью коэффициента отражения
}

\author{
Д.Ю. Протасов ${ }^{1,2}$, К.С. Журавлев ${ }^{1}$ \\ ${ }^{1}$ Институт Физики Полупроводников им. А.В. Ржанова, Новосибирск, \\ 630090, пр-т Академика Лаврентьева, 13 \\ ${ }^{2}$ Новосибирский государственный технический университет, \\ 2. Новосибирск, 630073, пр- $m$ Карла Маркса, 20 \\ тел:+7 (383) 333-1954, факс:+7 (383) 33090-29, эл.nочта: protasov@isp.nsc.ru
}

DOI 10.34077/RCSP2021-112

Светодиоды ближнего инфракрасного диапазона повышенной мощности активно применяются в системах видеонаблюдения, производстве ИК прожекторов и нагревателей, а также в системах автоматизации. Для создания таких светодиодов широко используют гетероструктуры на основе соединений $\mathrm{A}_{3} \mathrm{~B}_{5}$. Вывод излучения из гетероструктуры является одной из важнейших проблем мощных светодиодов, так как вследствие поглощающей подложки и высокого показателя оптического преломления в этих гетероструктурах наружу выходит несколько процентов излучения [1].

Для увеличения доли выходящего излучения используют несколько приемов [2], к наиболее важным относятся использование распределенного брегговского отражателя (РБО), позволяющего вывести наружу часть излучения, распространяющегося в сторону подложки, и создание шероховатости на поверхности гетероструктуры, в результате чего появляется возможность прохождения через границу раздела гетероструктура/воздух лучей, распространяющихся под углами, большими угла полного внутреннего отражения.

Недостатком РБО является резкое падение коэффициента отражения при углах падения, превышающих угол полного внутреннего отражения $\theta_{c}$ для границы раздела гетероструктура/воздух. Для GaAs угол полнового внутреннего отражения на длине волны 860 нм равен $\theta_{c} \approx 1 / n_{\text {GaAs }}=0,294$ рад или $16,9^{\circ}$. В результате этого, во-первых, уходят в подложку те лучи, которые распространяются под большими углами к нормали в сторону подложки, и во-вторых, теряют шанс на выход наружу лучи, распространяющиеся в сторону границы раздела гетероструктура/воздух и рассеянные шероховатой границей гетероструктуры на большие углы. В результате, внешняя квантовая эффективность таких светодиодов не превышает 10\% [3].

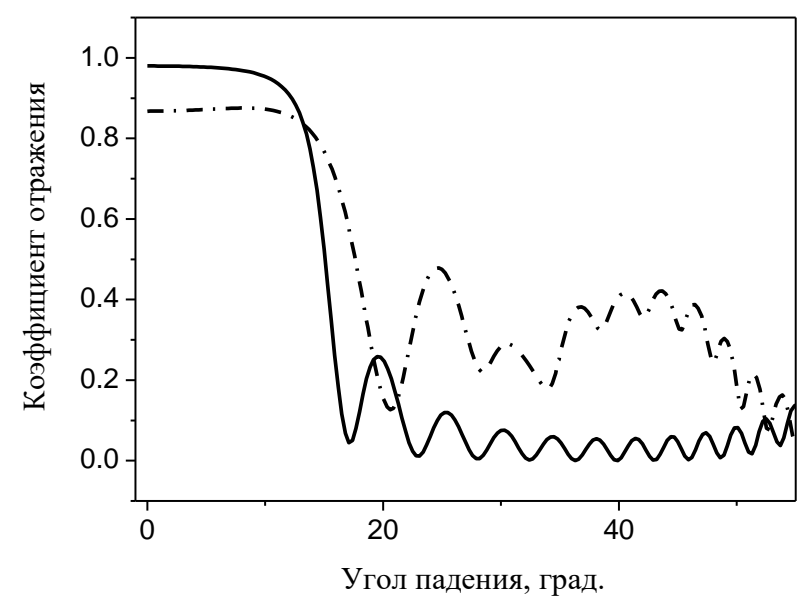

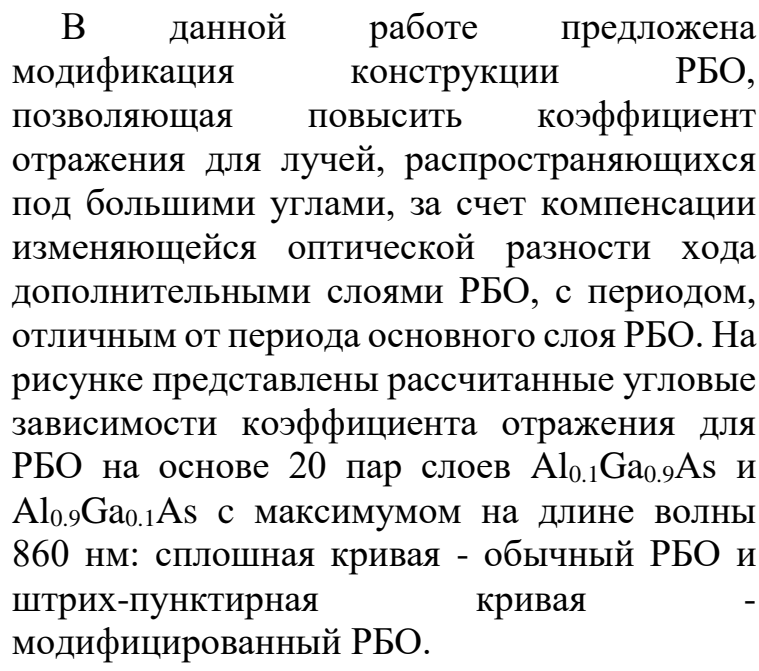

Как показывают результаты расчетов по представленным на рисунке зависимостям, доля света от ламбертовского источника, отраженная от модифицированного РБО, в 2.7 раза больше, чем для обычного РБО.

\section{Лumepamypa}

[1] M. R. Krames et al. // J. Displ. Techn. 2007. V. 3, No. 2. P. 160-175.

[2] E. F. Shubert. Light-Emitting Diodes. Second Edition. Cambridge University Press, New York, 2006. $422 \mathrm{P}$.

[3] А.В. Малевская и др. //ФТП. 2021. Т. 55, вып. 7. С. 614-617. 